\title{
Interdependence between core and peripheries of the European economy: secular stagnation and growth in the Western Balkans
}

\author{
Will Bartlett ${ }^{*}$ Ivana Prica*
}

\begin{abstract}
European countries are economically dependent upon each other. This paper therefore embeds the analysis of the Western Balkan countries within a wider perspective of the European economy as a whole. It combines a simple core-periphery model with an under-consumption model to provide an explanation of the emergence of secular stagnation, the dependency relationships between the core and peripheries of the European economy, and the spillover effects of Eurozone crisis to the Western Balkans. Due to tendencies to under-consumption, the core countries have been vulnerable to secular stagnation. In order to overcome this tendency within the Eurozone they are dependent on export revenues from the peripheries to sustain their economic growth. This has led to high trade and current account deficits during the boom and placed the peripheries in a highly vulnerable position during the recession period. Financialisation of the European economy has emerged as a response to the tendency towards secular stagnation, as the provision of consumer credit stimulated demand and temporarily overcame underconsumption tendencies. The paper argues that continuing austerity, as a method to create internal devaluation, is unlikely to succeed as a means to extricate the periphery countries from the crisis. Given the dependencies of the European economies upon one another, a possibly better way out of the current period of low growth and stagnation would be a coordinated fiscal expansion to stimulate domestic and Europe-wide demand.
\end{abstract}

JEL Classification: F42, O52, P52

Keywords: Secular stagnation, Western Balkans, core-periphery

\section{Introduction}

The Eurozone crisis can be understood as the outcome of a structural imbalance between "core" and "periphery" countries (Lapavitsas et al., 2010). Germany is at the centre of "core" group of countries in the Eurozone, while Greece, Italy, Portugal and Spain are conventionally seen as forming the "periphery" of the Eurozone. Yet other EU member states that are outside the Eurozone also belong to the European periphery, and form what we call the "outer periphery" of the EU. Countries of this outer periphery, such as Bulgaria and Romania are just as much affected by the Eurozone crisis as the "inner periphery" countries within the Eurozone, even though they have not adopted the Euro. The fortunes of their economies are affected by developments in the Eurozone, not just through flows of trade, investment and people, but also because the financial sectors are highly integrated.

Outside the EU, there is a further layer of countries that are neither Eurozone members nor EU members that are similarly influenced by developments in the EU and the Eurozone. Following Martin Sokol, these countries can be referred to as the "superperiphery" of the EU (Sokol, 2001). They comprise the countries of the Western Balkans and of the European Eastern Neighbourhood.

\footnotetext{
* European Institute, London School of Economics and Political Science, Email: w.j.bartlett@1se.ac.uk

** Faculty of Economics, University of Belgrade, Email: ivanapopov.prica@gmail.com
} 
A feature of these countries, especially in the Western Balkans, has been a widespread euroisation both among households and companies (Országhová, 2015). This has meant the Western Balkan countries have not been able to use devaluation as a means to improve the competitiveness of their economies. A high proportion of loans and savings are denominated in Euros, which inhibits the use of devaluation or depreciation of the currency as an instrument of macro-economic policy to improve the external competitiveness of their economies. At the same time, EU bailouts are unavailable to these countries. Therefore, the only option is internal devaluation, which requires decreased levels of prices and unit labour costs to bring about improved external competitiveness.

In this paper we identify the extent to which these peripheral countries are connected to and influenced by the evolution of the European economy as a whole, and how they have been consequently affected by the crisis in the Eurozone.

\section{Under-consumption in the capitalist core}

The Classical economists were preoccupied with the question whether there would be enough aggregate demand to buy all the goods and services produced by business enterprises. The theme was taken up by Keynes who argued that market economies were prone to a lack of effective demand and to the possibility of unemployment equilibrium (Keynes, 1936). The under-consumption theorists furthermore proposed that market economies were also prone to "secular stagnation" (Hansen, 1955; Steindl, 1952). ${ }^{1}$ Radical economists took this further, most notably in the work of Paul Baran and Paul Sweezy who argued that under "monopoly capitalism", employers strive to increase profits by pushing down wages, which reduces aggregate consumption (Baran and Sweezy, 1966). In a further development of the theory, they argued that the financial sector dominance has emerged as a means to maintain aggregate consumption. However, this has the unfortunate side effect of increasing instability in the economy (Minsky, 1986). The financialisation thesis suggests that financialisation generates instability and is a prime factor in economic stagnation, and can lead to debt-deflation and prolonged recession (Palley, 2007). Others have argued that stagnation is a more deep-seated phenomenon and that it is the tendency towards stagnation that generates financialisation rather than the other way round, and that a failure of financialisation to successfully play this role, the underlying tendency towards stagnation can reappear (Bellamy Foster and Magdoff, 2009). Moreover, financialisation has also generated gross inequality (Picketty, 2014), which further reduces consumption demand and reinforces the under-consumption problem.

Governments of advanced countries have several options for escaping from the under-consumption trap (Baran and Sweezy, 1966). First they can increase government spending in various forms. Social spending (pensions, social security) can be increased, but the limits of this appear when social spending begins to undermine work incentives. The public services such as education and health can be expanded through public expenditure, but the limits of this are reached under continuous pressure to introduce private provision of services. A strong contender for generating additional demand is through military expenditure (in 2015 the US military budget was $\$ 600$ billion). However, this also reaches its limits for countries that wish to pursue a peaceful nonaggressive foreign policy. Another way to generate increased demand in economies that

1 This idea has recently been revived by Summers (2013) 
suffer from under-consumption is to increase consumption through advertising and marketing expenditure. However, this also has its limits due to the finite needs of the population, although constant efforts are made to stimulate artificial desires.

A further important mechanism to stimulate demand is to rely upon demand from other countries and to promote exports, through measures that build a country's competitive advantage. This form of export-led growth is usually accompanied by central control over wage costs, combined with labour market reforms to reduce wage costs and promote the flexibility of the labour force. Many other measures are available to promote exports, and some countries are more successful in doing so than others. However, the limit of this approach is that all countries cannot do this at the same time. Some must be net importers if others are to be net exporters. This has been a central feature of the Eurozone arrangement, where the core countries have become net exporters and rely upon demand from the periphery counties to compensate for underconsumption on the domestic market.

Finally, additional demand can be generated through the development of consumer credit. If the workers do not have enough buying power from their wages, then they can be encouraged to take out consumer credit to fill the gap. This has led to the development of a very sophisticated market in consumer finance and to the general 'financialisation' of the advanced economies, generating additional consumption through the growth of consumer credit. But financialisation generates asset bubbles and financial crises, and so also has its eventual limits.

\section{Secular stagnation in the Eurozone}

The Euro was established in January 2002 as a monetary union without a fiscal union. Under this arrangement, the nominal interest rate set by the ECB is the same across all the member states. Since this common interest rate that is too high in some countries and too low in others, immense structural imbalances have grown over time. In particular, as Germany is a strong exporter, she has run structural current account surpluses, while the peripheral countries such as Greece, Spain, and Italy have run structural current account deficits. These deficits have led to a build up of debt in the peripheral countries that has contributed to the economic crisis that has beset the Eurozone since 2009.

In addition, the adoption of the Euro induced investors to believe that the debts contracted by the peripheral countries were just as credit-worthy as the debts incurred by the core countries such as Germany or the Netherlands. This led to a great inflow of foreign capital into the periphery countries and enabled them to sustain either an unjustified high level of wages and consumer spending as in the case of Greece, or a high level of asset price appreciation and housing boom as in the case of Spain.

In autumn 2009, following the election of the Pasok government, it was revealed that the Greek state had a far higher level of debt than had previously been thought. Investors suddenly realised that the periphery countries could not necessarily pay back their debts, and that more importantly, there was no guarantee that the core countries would bail out their debts within the single currency system (Pisani-Ferry, 2014). Panic ensued. The value of the government bonds in the periphery countries fell, and yields rose to unsustainable levels. Since then, the Eurozone has been involved in a vivid fire fighting exercise to restore calm. The periphery countries have been reluctantly bailed out though individual rescue schemes, culminating in the creation of the European Stability Mechanism, and the creation of a system of New Economic Governance, 
which has brought the fiscal policies of the individual Eurozone member states under the supervision, if not outright control, of the central authorities at the European Commission and the ECB. In addition, intra-Eurozone imbalances have been financed by the TARGET inter-bank settlement system adopted between the Eurozone central banks (Werner-Sinn, 2014).

Since the debts that governments issued were largely held by their own banks in the periphery countries, the banks also got into difficulties. As the value of the government bonds that they held fell, and they ran into danger of bankruptcy, the banks had to be bailed out by their own governments leading to a further increase in government deficits. This negative spiral of debt and collapse between the states and the banks became a key problem in preventing the resumption of economic growth (PisanyFerry, 2014).

The essence of the problem was that the Eurozone lacked an EU-wide "bank resolution" mechanism. When banks get into difficulties in sovereign countries, their own central banks have the ability to step in and bail them out (or recapitalise them) if needed, and can subject such banks to reorganisations and other regulatory procedures or close them down. In the Eurozone there was no single authority that had the power to step in and close down a bank in difficulty, or bail it out, thus relieving the bank's own state of the responsibility. Eventually, policy makers realised the need for a banking union (to accompany the monetary union) that would create a single authority to carry out these responsibilities. These institutions have now been established, through the European Banking Authority based in London and the increased power granted to the ECB to act as a banking supervisor with powers to "resolve" local banks in trouble in Eurozone member states.

The policies that have been adopted to restore balance in the Eurozone have been generalised austerity and cut backs in state spending, combined with increases in taxation, and a stability treaty was signed to restrict the government deficits of the Eurozone member states to 3\% of their GDP. In order to achieve these targets, public expenditure has been cut, further deepening recession and stagnation in the Eurozone. In order to restore the competitiveness of the economies of the inner periphery, internal devaluations have been imposed in an effort to reduce real wages and prices of exported goods.

The core countries have not been immune from their own difficulties, and have begun to experience secular stagnation as their economies have matured. ${ }^{2}$ The autonomous part of their growth has diminished and their economic growth has been propelled by exports to the rest of the EU. This has led to structural imbalances within the Eurozone with a semi-permanent trade surplus developing in the core countries. Since the countries in the peripheries are consumers of core country exports, this process generates trade and current account deficits in the peripheries. These deficits have been financed by borrowing from banking sector in the core countries largely though government bonds. This is an unsustainable equilibrium, as debts in peripheries grow ever higher and eventually cannot be financed. The peripheries cannot export its way out of debt through devaluation, due to the euro monetary system. The only

2 “Until 2006, Germany's growth was even slower than Italy's, turning the country into the Eurozone's laggard. ... in the period from the announcement of the euro at the Madrid summit to the year before the outbreak of the crisis, Germany experienced the lowest growth rate of all European countries" (Werner-Sinn, 2014: 85). 
alternatives are (a) bailouts or (b) internal devaluation (cutting unit labour costs and government expenditure through austerity programmes). But austerity leads to a further drop in aggregate domestic demand and to the prolongation of the recession.

\section{Financialisation of the super-periphery}

The period between the 'democratic turn' in Croatia and Serbia in 2000 and the start of the economic crisis in the region in 2009 was a period of strong economic expansion. This was accompanied by a rapid financialisation of the economies due to the rapid takeover of domestic banking system by foreign (mainly Eurozone) banks between 2000 and 2005 (see Figure 1).

Figure 1: Bank assets under foreign ownership, Western Balkans, 1998-2011 ( $\%$ of total bank assets)

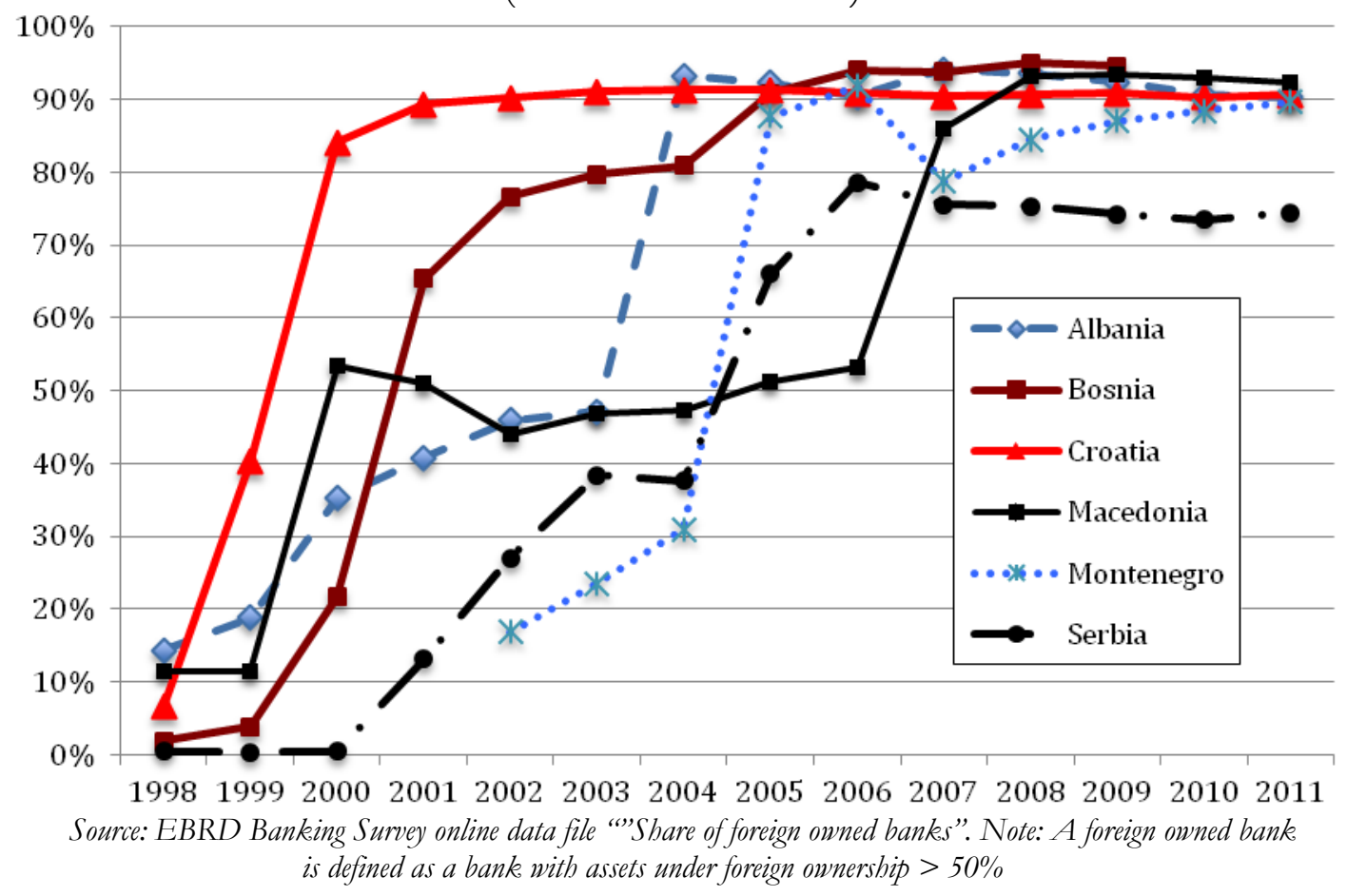

Financialisation enabled a credit boom that supported rapid economic growth as foreign banks poured new funds into the region. This in turn led to a huge increase in imports, mainly of consumer durables such as motorcars and household electrical goods that were much needed to replace the antiquated stock of vehicles and other consumer durables, and to a lesser extent machine tools and other equipment to upgrade the industrial sector. During this period, the Western Balkan countries ran large trade and current account deficits; by 2008, the trade deficit in the Western Balkans was running at an average rate of $35 \%$ of GDP. These deficits were associated with a build-up of international debt in the Western Balkan region as a whole from an average of $43 \%$ of Gross National Income (GNI) in 2001 to $58 \%$ in $2008 .^{3}$

3 Unweighted average of Western Balkan countries' external debt to GNI ratio (excluding Kosovo), derived from World Bank Development Indictors online database. 
The strong inflow of foreign capital, along with falling interest rates, led to rapid credit growth up to 2008. However, this process has gone into reverse since, following the onset of the crisis, Eurozone banks have tried to restore their domestic capital base and have been "deleveraging" from the Western Balkans. ${ }^{4}$ In response to this process, the IFIs have provided $€ 24.5 \mathrm{bn}$ loans to 17 Eurozone parent banks with affiliates in Central and South East Europe through an arrangement known as the Vienna Initiative (EBRD et al., 2011). Later, the "Vienna Plus" agreement (Vienna Initiative 2.0) aimed to encourage substitution of foreign borrowing by local currency borrowing and more efficient absorption of EU structural funds. ${ }^{5}$

\section{Eurozone crisis and the peripheries of Europe}

Since the onset of the Eurozone crisis, the inner periphery ${ }^{6}$ has experienced a dramatic economic recession that has been widely commented and analysed (Croci Angelini et al., 2016; Botta, 2014; De Grauwe, 2013). The outer periphery ${ }^{7}$ has also suffered from the spillover effects of the Eurozone crisis although the effect of the Eurozone crisis on this group of countries has been far less widely covered with some notable exceptions (Connolly, 2012, 2014).

The super-periphery, including the Western Balkan countries, was also severely hit by the global financial crisis and subsequently by the Eurozone crisis after 2009 experiencing a double-dip recession in 2012 and virtual stagnation over the whole postcrisis period (Bartlett and Prica, 2013). Initially there was a very strong reduction in export demand, and although though this soon picked up it was followed by a remarkable collapse in credit growth, a reduction in FDI inflows and an eventual fall in remittance inflows. Although exports have recovered as a share of GDP, they have remained below $50 \%$ of GDP in all the Western Balkan countries, and below $40 \%$ of GDP in Albania, Bosnia and Herzegovina, and Kosovo. According to a recent study, exports from the region are far below their potential, ${ }^{8}$ taking into account the geographic closeness to the EU market and a range of other standard determining factors (World Bank, 2014). Even before the crisis, FDI flows to the Western Balkans were relatively low, due to structural factors such as the weak institutional environment for investors (Estrin and Uvalić, 2014), and have fallen further since 2009. Initially, remittances held up in most countries following the onset of the crisis, but more recently these have also declined, especially in Albania, and Bosnia and Herzegovina, as the crisis led to tighter labour market conditions in countries such as Greece and Italy, where many migrants lost their jobs and could no longer so easily send money home to their families (Pula, 2014). Many companies in the super-periphery have experienced

\footnotetext{
${ }^{4}$ It should be noted that deleveraging has taken place elsewhere in Central and Eastern Europe, not just in the Western Balkans

${ }^{5}$ See: http://vienna-initiative.com/vienna-initiative-part-2/mission-statement/

${ }^{6}$ As explained above, we refer to the peripheral countries within the Eurozone as the "Inner Periphery", the countries within the EU but outside the Eurozone as the "Outer Periphery", and the European countries that are outside in the EU but strongly integrated through euroisation and trade and investment links, as the "Super-Periphery".

7 See footnote 4 .

8 The gravity model used to derive this conclusion shows the deficiency in exports ranging from $40 \%$ below potential in Albania to $27 \%$ below potential in Kosovo, Montenegro and Serbia.
} 
difficulties in paying back the loans they took out during the boom period due to the fall in demand during the recession, and in some cases to governments' tactics of delaying payments in order to meet budget deficit targets. This in turn has led to a huge increase in non-performing loans. ${ }^{9}$ Furthermore, many foreign banks have pulled funds out of the region through a process of deleveraging. ${ }^{10}$

The outcome of these spillovers from the Eurozone crisis has been a prolonged period of slow growth encompassing a double-dip recession in 2009 and 2012. The average rate of growth in the Western Balkan countries has fallen from a pre-crisis average of around $5.6 \%$ p.a. in 2003-08, to an average of $1.3 \%$ p.a. in $2009-14 .{ }^{11}$ At the same time, unemployment has risen to dramatically high levels - among the highest in Europe (Kovtun et al. 2014) - and in Bosnia and Herzegovina to levels exceeding that in Greece. This has led to a re-emergence of high levels of both actual and felt poverty in the super-periphery, especially in Albania, Montenegro and Serbia (Koczan, 2016). In contrast, Bulgaria and Romania, in the outer periphery, have not suffered such dire consequences, as unemployment levels have remained nearer to the EU average of $10 \%$ (see Figure 2).

Figure 2: Unemployment rates in South East Europe and the EU-28 in 2014 (\%)

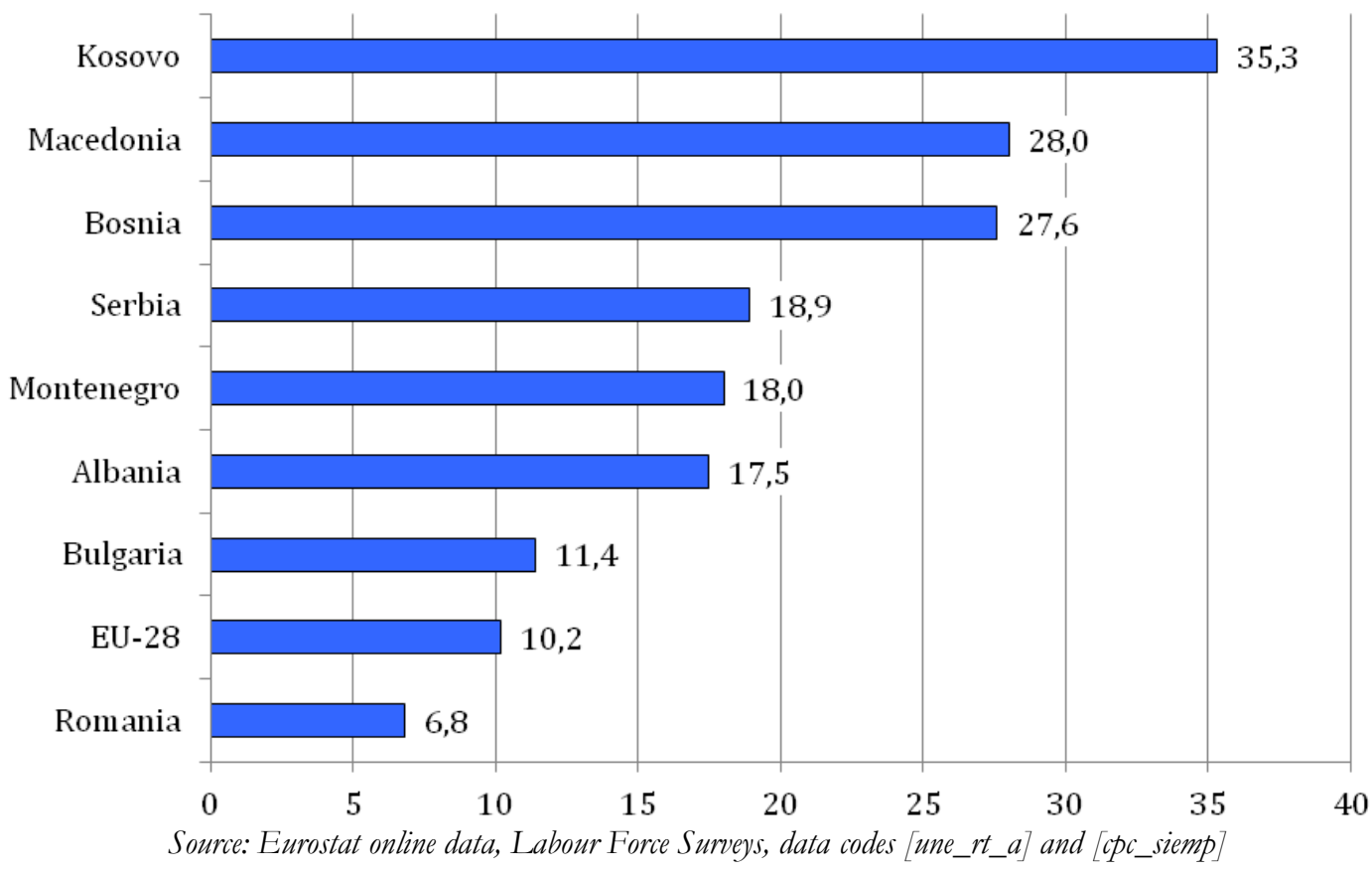

Prior to the crisis, the international debt had been relatively modest, but following the onset of the crisis the stock of international debt in the Western Balkans further

9 The Vienna 2.0 Initiative has been especially concerned with the dramatic increase in non-performing loans in the region. See "Vienna Initiative pushes for action plan to deal with NPLs in central and south-eastern Europe", Press Release, 26 September 2014 [http://vienna-initiative.com/wpcontent/uploads/2014/10/NPL-Press-Release.pdf].

10 This has been documented in detail through the regular reports of the "CESEE Deleveraging and Credit Monitor", published by the Vienna Initiative [http://vienna-initiative.com/wpcontent/uploads/2016/02/DCM-note_Jan2016_official_final1.pdf]

${ }^{11}$ Unweighted average calculated from Eurostat online data variable code [cpc-sigeb] 
increased to $63 \%$ of GNI in $2014 .^{12}$ Public debt has also increased dramatically due to falling tax revenues combined with a large share of mandatory expenditures to cover public sector wages and pensions (Koczan, 2015).

\section{Growth dependency between core and periphery}

The core-periphery model, combined with the theory of under-consumption, suggests that economic growth in the core is dependent on growth in the peripheries, and vice versa. Without the demand for exports from the peripheries, the core would likely be subject to secular stagnation. At the same time, without financial transfers from the core, the peripheries would be subject to unsustainable balance of payments crises.

This section develops a modelling approach to identify the relationship between the core and the peripheries, and to investigate the extent to which the core and peripheries are dependent on each other.

The model is set out as follows. The growth of country $i$ at time $t$ depends on an autonomous component $\beta_{0}$, and on the growth of the EU as a whole, Growth $\mathrm{EUt}_{\mathrm{t}}$ at time t. The extent of the dependency is represented by coefficient $\beta_{1}$. A dummy variable is introduced that captures the effect of the Eurozone crisis of country $i$ at time $t$, which takes the value 1 for the years 2009-2013, and 0 otherwise, with coefficient $\beta_{2}$. The model is set out in equation 1:

$\mathrm{G}_{\mathrm{it}}=\beta_{0}+\beta_{1} *$ Growth $_{\mathrm{EUt}}+\beta_{2} *$ Crisis $_{\mathrm{it}}+\mathrm{u}_{\mathrm{it}}$

Where

$\beta_{0}$ represents autonomous growth capacity

$\beta_{1}$ represents dependency on EU growth

$\beta_{2}$ represents the effect of the crisis on autonomous growth

The data used to analyse the model is taken from EUROSTAT. Available data on annual real GDP growth rates for the EU countries and the enlargement countries span the years from 1996-2014 ( $\mathrm{N}=19)$. While this is a small sample, it is nevertheless a consistent dataset. We divide countries into five groups:

12 Unweighted average, calculated from World Development Indicators database. Croatia and Kosovo are not included due to lack of available data. 


\section{Country group}

Core countries within the Eurozone and the EU (Inner Core)

Core countries outside the Eurozone, within the EU (Outer Core)

Periphery countries within the Eurozone and the EU (Inner Periphery)

Periphery countries outside the Eurozone, within the EU (Outer Periphery)

Periphery countries, outside the Eurozone and the EU but with currencies tied to the Euro (Super Periphery)

\section{Countries}

Austria, Belgium, Finland, France, Germany, Netherlands

Czech Republic, Denmark, Estonia, Latvia, Lithuania, Poland, Slovakia, Sweden, United Kingdom

Cyprus, Greece, Ireland, Italy, Portugal, Spain

\section{Bulgaria, Hungary, Romania}

Albania, Croatia, FYR Macedonia, Serbia

Table 1 shows the estimates for a set of countries in the Eurozone core. The dependent variable is the real GDP growth rate of the country in question. The independent variables are the growth rate of the EU27 calculated without the country in question, based on chain linked volume indices of GDP obtained from Eurostat (hence "EU27-1"), and a crisis dummy where $\mathrm{D}=0$ for all years prior to 2009 and $\mathrm{D}=1$ thereafter.

Table 1: Inner Core countries dependency on EU27-1

\begin{tabular}{l|l|l|l|l|l|}
\hline Country & $\boldsymbol{\beta}_{0}$ & $\boldsymbol{\beta}_{1}$ & $\boldsymbol{\beta}_{2}$ & Breusch-Pagan (sig.) & $\begin{array}{l}\text { Adjusted } \\
\text { R-squared }\end{array}$ \\
\hline Finland & -0.23 & $1.68^{* * *}$ & -0.60 & 0.20 & 0.944 \\
Germany & $-2.08^{* * *}$ & $1.40^{* * *}$ & $3.15^{* * *}$ & 0.05 & 0.771 \\
\hline Austria & 0.35 & $0.90^{* * *}$ & 0.16 & 0.82 & 0.858 \\
Netherlands & 0.73 & $0.88^{* * *}$ & -1.01 & 0.26 & 0.775 \\
France & 0.21 & $0.80^{* * *}$ & 0.26 & 0.60 & 0.871 \\
Belgium & 0.48 & $0.77 * * *$ & 0.08 & 0.18 & 0.816 \\
\hline $\begin{array}{l}\text { Mean } \\
\text { Note: *** indicates 1\% significance level; ** indicates 5\% significance level; * indicates 10\% significance level. The Breusch- }\end{array}$ \\
Pagan test for heteroscedasticity with Ho=constant variance. Results are sorted by column $\boldsymbol{\beta}_{1}$
\end{tabular}

The results reported in Table 1 reveal that the inner core countries are subject to a tendency towards under-consumption, as the coefficients on the constant term that represents autonomous growth are negative or insignificantly different from zero. In contrast, the coefficients on the variable $\beta_{1}$, which represents the dependency on EU growth, are positive and highly significant. For Finland and Germany the coefficients are greater than 1, which indicates that for each percentage point increase in the EU growth rate, their growth rate increases by more than a percentage point. Therefore, their gain from EU growth through exports and in other ways seems to have offset the tendency towards secular stagnation to which their economies are prone. The core is indeed dependent on the Periphery.

The coefficients on the crisis dummy are on the whole positive although only statistically significant for Germany, which shows that the core countries have not been 
significantly affected by the crisis, or have even benefitted from it (for example through domestic stimulus measures).

Only one of the regressions (Germany) shows signs of autocorrelation (the Breusch-Pagan test is significant at the $10 \%$ level), which could introduce difficulties in interpreting the t-statistics.

Table 2: Inner Periphery dependency on EU27-1

\begin{tabular}{|c|c|c|c|c|c|}
\hline Country & $\boldsymbol{\beta}_{0}$ & $\boldsymbol{\beta}_{1}$ & $\boldsymbol{\beta}_{2}$ & Breusch-Pagan (sig.) & $\begin{array}{l}\text { Adjusted } \\
\text { R-squared }\end{array}$ \\
\hline Greece & $3.41 * * *$ & 0.08 & $-8.15^{* * *}$ & 0.21 & 0.722 \\
\hline Italy & $-1.37 * * *$ & $1.07^{* * *}$ & -0.09 & 0.68 & 0.919 \\
\hline Portugal & 0.45 & $0.76^{* * *}$ & -1.68 & 0.80 & 0.594 \\
\hline Slovenia & $1.25^{* *}$ & $1.27^{* * *}$ & $-2.33 * * *$ & 0.74 & 0.863 \\
\hline Spain & $2.06^{* * *}$ & $0.67^{* * *}$ & $-3.09 * * *$ & 0.14 & 0.910 \\
\hline Ireland & $2.42 *$ & $1.62^{* * *}$ & -2.35 & 0.68 & 0.641 \\
\hline Cyprus & $2.61^{* * *}$ & $0.54^{* *}$ & $-4.30 * * *$ & 0.04 & 0.787 \\
\hline Mean & 1.55 & 0.86 & -3.14 & & \\
\hline
\end{tabular}

Table 2 shows the results for the Inner Periphery group of countries. Here, autonomous growth potential is mainly positive with the exception of Italy as indicated by the positive values of the constant term, most of which are highly significant (with the exception of Ireland and Portugal). Growth dependency, indicated by coefficient $\beta_{1}$ is also positive, except in the case of Greece, and in several countries greater than 1 (Ireland, Italy and Slovenia). Unlike the core countries, the negative coefficients on $\beta_{1}$, the crisis dummy, are uniformly negative, and not surprisingly extremely high in the case of Greece. Autocorrelation appears as a problem in the regressions for Cyprus (Breusch-Pagan test significant at 5\% level) suggesting that the standard errors for these may be over-estimated.

Table 3: Outer Core: dependency on EU27-1

\begin{tabular}{|c|c|c|c|c|c|}
\hline Country & $\boldsymbol{\beta}_{0}$ & $\boldsymbol{\beta}_{1}$ & $\boldsymbol{\beta}_{2}$ & Breusch-Pagan (sig.) & $\begin{array}{l}\text { Adjusted } \\
\text { R-squared }\end{array}$ \\
\hline Estonia & -0.55 & $2.92 * * *$ & 1.49 & 0.90 & 0.609 \\
\hline Latvia & 1.45 & $2.17 * * *$ & -1.40 & 0.63 & 0.492 \\
\hline Lithuania & 1.54 & $2.04 * * *$ & -0.89 & 0.77 & 0.478 \\
\hline Sweden & -0.61 & $1.53 * * *$ & $1.87 * * *$ & 0.34 & 0.880 \\
\hline Denmark & -0.59 & $1.08^{* * *}$ & 0.27 & 0.21 & 0.836 \\
\hline Slovakia & $3.04^{* *}$ & $0.91 *$ & -1.69 & 0.19 & 0.367 \\
\hline Czech & 1.25 & $0.90 * * *$ & -1.20 & 0.16 & 0.452 \\
\hline UK & $1.05^{* *}$ & $0.74 * * *$ & $-1.13^{*}$ & 0.11 & 0.734 \\
\hline Poland & $3.61 * * *$ & $-0.41 *$ & -0.54 & 0.51 & 0.227 \\
\hline Mean & 1.13 & 1.32 & -0.36 & & \\
\hline
\end{tabular}


Table 3 shows the results for the countries of the outer core, i.e. the countries not in the Eurozone but within the EU core group. Two regressions for this group indicate very strong autonomous growth potentials: Poland and Slovakia. The dependency of outer core countries on the EU growth is positive, and very strong in the cases of Estonia, Latvia, Lithuania and Sweden. The coefficient even exceeds a value of 2 for the Baltic countries.

Table 4: Outer Periphery: dependency on EU27-1

\begin{tabular}{|c|c|c|c|c|c|}
\hline Country & $\boldsymbol{\beta}_{0}$ & $\boldsymbol{\beta}_{1}$ & $\boldsymbol{\beta}_{2}$ & Breusch-Pagan (sig.) & $\begin{array}{l}\text { Adjusted } \\
\text { R-squared }\end{array}$ \\
\hline Hungary & 0.64 & $1.08^{* * *}$ & -0.60 & 0.94 & 0.588 \\
\hline Bulgaria & 2.38 & 0.61 & -2.19 & 0.21 & 0.190 \\
\hline Romania & 3.05 & 0.38 & -3.02 & 0.55 & 0.103 \\
\hline Mean & 2.02 & 0.69 & -1.94 & & \\
\hline
\end{tabular}

Among the outer periphery group, the two SEE countries, Bulgaria and Romania, show strong autonomous growth potential (high coefficients on $\beta_{0}$ ). However, in relation to growth dependency, the values of the $\beta_{1}$ coefficient are less than 1 , suggesting a weak dependency and a lesser gain from EU economic relations than for the other countries in the outer core (compare Tables 2 and 3). Both countries have experienced a severe adverse impact of the Eurozone crisis.

Table 5: Super-Periphery countries dependency on EU27

\begin{tabular}{l|l|l|l|l|l|}
\hline Country & $\boldsymbol{\beta}_{0}$ & $\boldsymbol{\beta}_{1}$ & $\boldsymbol{\beta}_{2}$ & $\begin{array}{l}\text { Breusch-Pagan } \\
\text { (sig.) }\end{array}$ & $\begin{array}{l}\text { Adjusted } \\
\text { R-squared }\end{array}$ \\
\hline Croatia & $2.38^{* *}$ & $0.67^{*}$ & $-4.48^{* * *}$ & 0.53 & 0.681 \\
Macedonia & 1.56 & 0.61 & -0.27 & 0.31 & 0.122 \\
Serbia & 3.74 & 0.20 & -3.96 & 0.13 & 0.088 \\
Albania & $5.73^{* *}$ & 0.00 & -3.62 & 0.13 & 0.022 \\
\hline Mean & 3.36 & 0.37 & -3.08 & Note: $* * *$ indicates 1\% significance level; ** indicates 5\% significance level; * indicates 10\% significance level. The Breusch- \\
Pagan test for heteroscedasticity with Ho=constant variance. Results are sorted by column $\boldsymbol{\beta}_{1}$
\end{tabular}

Table 5 shows results for the super-periphery group of countries. Most regressions for this group indicate very strong autonomous growth potentials, with the coefficients of the constant term having a high level of statistical significance in the cases of Albania and Croatia. This implies that, even in the absence of EU membership, the countries could achieve a high rate of economic growth under the right conditions. There is clearly a large potential for catch-up growth in this group.

The dependency of super-periphery countries on the EU growth is weak, with no countries having a coefficient on $\beta_{1}$ greater than unity. Only Croatia has a statistically significant positive coefficient. The low coefficients on $\beta_{1}$ suggest that the superperiphery is not dependent on the core. Hence, catch-up growth in the super-periphery could be "autonomous" and could feasibly be generated by internal demand, and by 
exports to other countries within the region and elsewhere in the world. In this respect the CEFTA free trade agreement to which these countries belong could play an important role.

The crisis effects in the super-periphery are uniformly negative and large with the exception of Macedonia, as shown by the coefficients on $\beta_{2}$. Interestingly, Macedonia is the only country in the region where unemployment rates have fallen during the crisis, in part due to successful macroeconomic policies and to a successful attempt to attract foreign investors into low-tax industrial and technology zones.

Table 5: Use of robust standard errors to resolve autocorrelation

\begin{tabular}{|l|l|l|l|l|}
\hline & $\boldsymbol{\beta}_{0}$ & $\boldsymbol{\beta}_{1}$ & $\boldsymbol{\beta}_{2}$ & $\mathbf{F}(\mathbf{2 , 1 6 )}$ \\
\hline Cyprus & $2.61^{* * *}$ & $0.54^{*}$ & $-4.30^{* * *}$ & 19.59 \\
Germany & $-2.08^{* *}$ & $1.40^{* * *}$ & $3.15^{* * *}$ & 21.97 \\
\hline
\end{tabular}

Note: *** indicates 1\% significance level; ** indicates 5\% significance level; * indicates $10 \%$ significance level.

To deal with the problem of possible autocorrelation in the cases of Cyprus and Germany, the relevant regressions were re-estimated using the robust standard errors procedure within STATA. The results are presented in Table 5. Here, as above, $\beta_{1}$ is the coefficient on current growth rate in the EU, $\beta_{2}$ is the coefficient on the crisis dummy variable, while $\beta_{3}$ is the coefficient on the lagged dependent variable. While the values of the coefficients remain the same, the overall significance level of the estimates is improved (although the significance level for $\beta_{1}$ for Cyprus has decreased from the $5 \%$ to the $10 \%$ level).

Table 6: Mean values of coefficients by country group

\begin{tabular}{|l|l|l|l|l|}
\hline Country Group & Mean $\boldsymbol{\beta}_{0}$ & Mean $\boldsymbol{\beta}_{1}$ & Mean $\boldsymbol{\beta}_{2}$ & $\begin{array}{l}\text { Mean } \boldsymbol{\beta}_{\mathbf{0}}+ \\
\text { Mean } \boldsymbol{\beta}_{2}\end{array}$ \\
\hline Inner Core & -0.09 & 1.07 & 0.34 & 0.25 \\
\hline Outer Core & 1.13 & 1.32 & -0.36 & 0.77 \\
\hline Inner Periphery & 1.26 & 0.89 & -2.80 & -1.54 \\
Outer Periphery & 2.02 & 0.69 & -1.94 & 0.08 \\
\hline Super Periphery & 3.36 & 0.37 & -3.08 & 0.27 \\
\hline
\end{tabular}

Source: Table 2-5 above

Table 6 summarises the results of the analysis by country group, which shows average values of the estimated coefficients for each group of countries. It can be seen that the autonomous growth coefficient $\beta_{0}$ differs by country group, being negative for the inner core countries. This indicates that the inner core countries may be suffering from secular stagnation and under-consumption that is relieved by the export demand coming from the peripheries. The mean value of this coefficient is progressively higher for the inner periphery, followed by the outer periphery and then the super-periphery where it reaches a value of 3.4. This indicates that the more peripheral a country is to the Eurozone, the greater is the autonomous growth component, and the greater the potential for catching up. The data is presented in Figure 2, showing clearly the differences between the country groups. 
Will Bartlett, Ivana Prica, Interdependence between core and peripheries of the European economy: secular 135 stagnation and growth in the Western Balkans

Figure 2: Parameter values for country groups

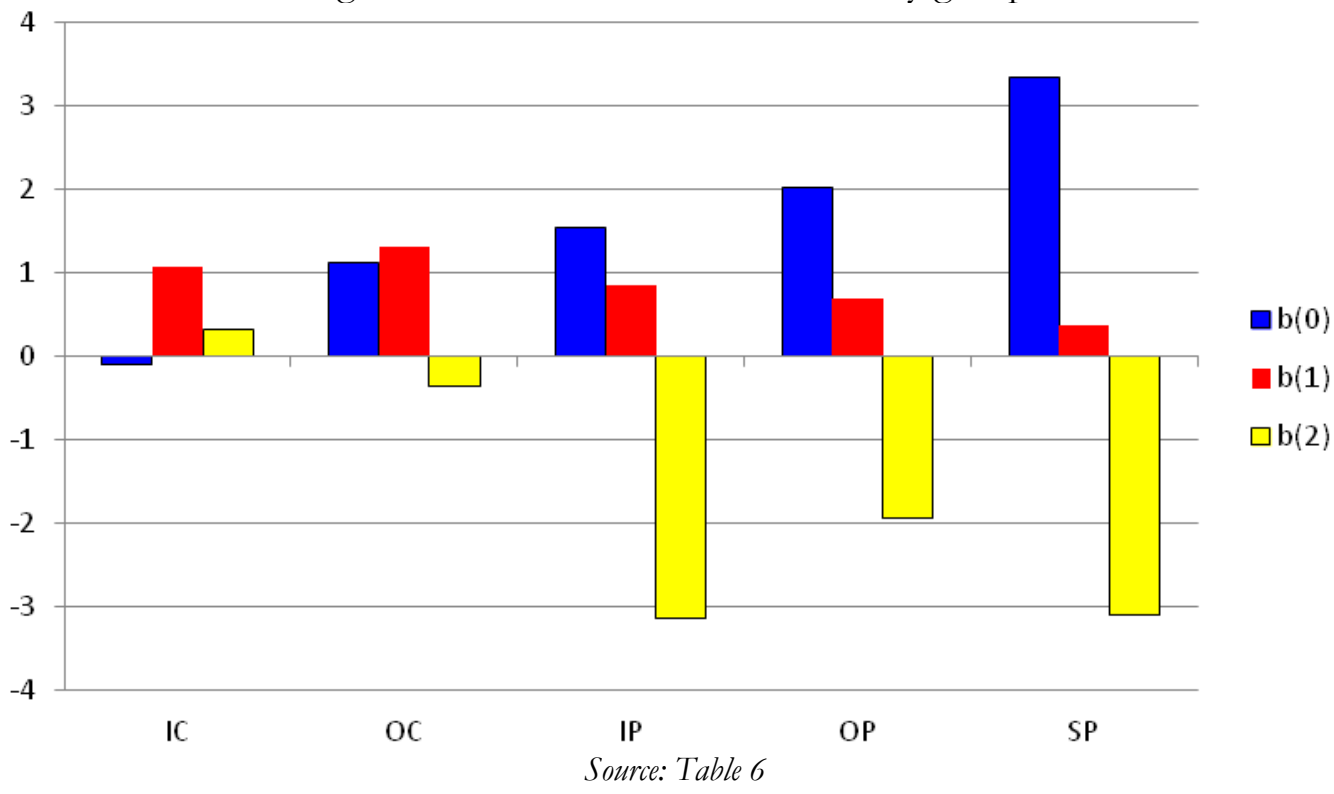

The average of the coefficients $\beta_{1}$, which reflects the degree to which individual country growth rates are dependent upon the growth rate of the EU, also differs between groups of countries. The core countries (both inner and outer) have a mean value of this coefficient that is greater than unity. This implies that for each percentage point increase in EU growth, the core countries experience a more than one percentage point increase in their own growth rate (on average). The implication is that the core countries benefit more than proportionately from EU growth, and this offsets (at least to some extent) their propensity to negative or low autonomous growth. The peripheries have relatively low coefficients of dependency on the EU, with mean values less than 1.0 for each group, and becoming progressively lower as one moves from the inner periphery to the super-periphery. This implies that each one percentage point growth of the EU has a less than one percentage point impact on growth in the countries within the peripheries.

Turning to the crisis effects, shown by the average of the coefficients $\beta_{2}$, the greatest effect is seen in the inner periphery and the super-periphery, with a similar impact in both groups of countries. The outer periphery has been affected to a slightly lesser extent by the crisis. At the same time, the inner core group of countries have actually gained from the crisis in terms of growth effects, compared to the non-crisis years. This may be due to the fact that they have not had to endure austerity policies, and to the stimulus policies that were applied initially in the inner core group.

The final column in Table 6 presents the net effect of the crisis, combining both autonomous growth and the crisis impact together. This shows that the crisis had the perverse effect in the inner core countries of offsetting the negative autonomous growth and producing a small positive growth effect during the crisis period. The two effects balanced each other out almost completely in the outer periphery. The greatest net effect was in the inner periphery, while in the super-periphery the net effect was negative but at a lower level. 


\section{Austerity policies}

In the peripheries, austerity programmes accompanied by structural reforms have involved a variety of measures, including cuts to public expenditure (education, health services, pensions, public employment) and labour market reforms to drive down unit labour costs. By 2014, only the UK and France had lower levels of severance pay in case of redundancy than the Western Balkan countries. In the super-periphery, substantial labour market reforms and cuts to pensions have been implemented in Serbia. Many countries have sought to reform pensions though reductions in entitlements (Bosnia and Herzegovina, Serbia). Most countries have tried to meet ambitious targets for public sector deficits (Bosnia and Herzegovina and Macedonia have cut their deficits to $2 \%$ of GDP). Cuts have also been introduced in public sector employment and public sector wages. Tax reforms have been introduced in the form of flat taxes that are now in place in several countries in the super-periphery (Macedonia, Albania).

While the countries of the inner periphery within the Eurozone have been supported by EU bailout funds, the IMF has supported the countries of the outer periphery and the super-periphery through stand-by arrangements and other measures. In 2009 the IMF agreed Stand-By Arrangements with Romania (€3.5bn Romania), Bosnia and Herzegovina (€1.1bn), and with Serbia (€402.5m) all of which have involved strict conditionality in relation to fiscal consolidation and economic reform measures. For example, Bosnia and Herzegovina has been under a US $\$ 405 \mathrm{~m}$ stand-by arrangement with IMF since 2012 that has mandated a tight austerity package designed to reduce the budget deficit, which was cut to 4.5\% of GDP in 2010, 2.5\% in 2012 and $2.0 \%$ in 2013. This was achieved through cuts to rights-based pensions and public sector wages. Serbia agreed a $\$ 1.5 \mathrm{bn}$ IMF stand-by arrangement 2009, which lasted until 2011 and mandated a nominal freeze in public pay and pensions. Subsequently the Serbian government deficit increased to $7 \%$ in 2013. Emergency measures to reduce the deficit in 2014 involved a 10\% cut to public sector pay and employment and the elimination of subsidies to 153 state owned firms employing 60,000 people. Macedonia was the recipient of a precautionary programme from the IMF, and has maintained a low budget deficit at 2.5\% of GDP in 2010 and 2011 achieved through a two-year public sector pay freeze. The deficit subsequently has increased again to $4.1 \%$ of GDP in 2013 and to even more in 2014 supporting a rebound in growth to the highest in the region at $3.8 \%$ in that year. It is not difficult to conclude that fiscal consolidation associated with these austerity policies has reduced domestic demand and undermined growth, offsetting many of the benefits of increased competitiveness associated with the structural reforms have been introduced.

Despite the rhetoric of austerity and structural reform, the core countries have practiced the opposite, and little in the way of structural reforms has been introduced in the core. For example, Germany is in 28th place out of 34 countries ranked by OECD for reform progress since the onset of the crisis. In place of austerity, Germany has introduced policies that have cut the pension age to 63 , or even 61 in certain cases, has increased minimum wages to relatively high levels, and has introduced industrial subsidies for green energy producers through the Energiewende (Energy change) programme that subsidises renewable energy producers. 


\section{Conclusions}

This paper considers the dependency of economic growth in individual European countries on the growth performance of the EU. In this way it embeds the analysis of the Western Balkan countries within a wider perspective of the European economy as a whole. The analysis is based upon a simple core-periphery model of the European economy. The paper identifies three distinct peripheries of the EU. An Inner Periphery consists of those countries that are in the Eurozone but have suffered a deep recession as a result of the Eurozone crisis. An Outer Periphery consists of those countries that are within the EU but outside the Eurozone. They have also been drawn into the Eurozone crisis as a consequence of spillovers from the crisis. However, they have benefited from being within the EU to the extent that their economies are supported by large inflows of structural funds. The third is a Super-Periphery that consists of countries that are outside both the Eurozone and the EU, but which are nevertheless tied to the Eurozone through a high level of euroisation of their economies. They are consequently unable to use depreciation of their currencies as a means to gain competitive advantage without causing large scale bankruptcies of domestic businesses, and personal defaults by mortgage holders who have typically borrowed in Euros or in Euro-indexed local currency loans.

The theory of under-consumption shows how the core countries are vulnerable to secular stagnation and how, in order to overcome this tendency within the Eurozone, they are dependent on export revenues achieved by trading with the less competitive periphery countries to sustain their economic growth. The import bill that this implies for the periphery countries (at each level) imply continuous trade and current account deficits and a steady build up of debt.

In the 2000s, the process of financialisation stimulated and supported an artificial economic boom in the peripheries. Indeed, financialisation was also a product of the tendency towards secular stagnation, as the provision of consumer credit was an important way in which the core countries were able to stimulate demand and overcome their under-consumption tendencies. The phenomenon of financialisation has also spread to the peripheries, making them vulnerable to the additional financial effects of the crisis.

The combination of a theory of core-periphery and a theory of underconsumption provides an explanation of the dependency relationships between the European economies and of the spillover effects of Eurozone crisis to the Western Balkans. Continuing austerity, as a method to create internal devaluation in the core, is unlikely to succeed as a means to extricate these countries from crisis; and due to their lack of competitiveness, a process of export-led growth is an unlikely outcome. Given the dependencies of the European economies upon one another, a possibly better way out of the current period of low growth and stagnation would be a coordinated fiscal expansion to stimulate domestic and Europe-wide demand, led by a Europe-wide investment programme focused on renewing the infrastructure assets in the peripheries, and especially in the super-periphery where autonomous growth potential has been shown to be extremely high. The European Investment Bank could fund these expansionary investment expenditures. In order to facilitate an increase in domestic capital formation and absorption of FDI in the Western Balkans such measures would also need to be backed up by serious reforms to the rule of law, in place of current 
cosmetic attempts to meet EU accession conditionality. ${ }^{13}$ In addition, policy makers would need to pay more attention to the consequences of fiscal expansion on poverty and inequality. In this respect, fiscal reform should involve changes to the tax system away from the widely adopted and regressive "flat" tax regimes, combined with a more robust social safety net than is currently in place. ${ }^{14}$

\section{Acknowledgements}

An early version of this paper was presented at the conference "Economic Growth: Stimuli and Constraints" on 24th - 25th April 2015, at the University of Pavia. It was subsequently presented at the First World Congress of Comparative Economics, Rome, 25th-27th June 2015, and the SSEES100 Conference "Achievements and Challenges for the Emerging Economies of Central Europe", London 22th- 24th June 2015. We are grateful for the useful comments received from participants at these conferences.

\section{References}

Baran P., Sweezy P. (1966), Monopoly Capital: An Essay on the American Economic and Social Order, New York, Monthly Review

Bartlett W., Prica I. (2013), 'The deepening crisis in the European super-periphery', Journal of Balkan and Near Eastern Studies, 15(4), 367-382

Bellamy Foster J., Magdoff F. (2009), The Great Financial Crisis, New York, Monthly Review Press

Botta A. (2014) 'Conflicting claims in the Eurozone? Austerity's myopia and the need for a European Federal Union in a post-Keynesian Eurozone centre-periphery model', Review of Keynesian Economics, 2(1), 45-70

Connolly R. (2012), 'The determinants of the economic crisis in post-socialist Europe', EuropeAsia Studies, 64(1), 35-67

Connolly R. (2014), 'Developments in the economies of Member States outside the Eurozone, Journal of Common Market Studies, 51, 201-218

Croci Angellini E., Farina F., Valentini E. (2016) 'Contagion across Eurozone's sovereign spreads and the Core-Periphery divide', Empirica, 43(1), 197-213

De Grauwe P., Yuemei J. (2013), 'Self-fulfilling crises in the Eurozone: an empirical test', Journal of International Money and Finance, 34, 15-36

EBRD, EIB, WBG (2011), Final Report on the Joint IFI Action Plan, London, The European Bank for Reconstruction and Development (with the European Investment Bank and the World Bank Group)

Estrin S., Uvalić M. (2014), 'FDI into transition economies: are the Balkans different?' Economics of Transition, 22(2), 281-312

\footnotetext{
13 See Fagan and Sincar (2015).

14 The extremely low coverage of last-resort social safety nets in the Western Balkans is identified in Gotcheva and Sundaram (2013)
} 
Fagan A., Sincar I. (2015), 'Judicial independence in the Western Balkans: is the EU's 'new approach' changing judicial practice?' MAXCAP Working Paper, 11, Freie Universität Berlin

Gotcheva B., Sundaram R. (2013), 'Social safety nets in the Western Balkans: design, implementation and performance', in: C. Ruggeri Laderchi, S. Savastano (eds.), Poverty and Exclusion in the Western Balkans: New Directions in Measurement and Policy, Berlin, Springer, 221-224

Hansen A. (1954), 'Growth or stagnation in the American economy', The Review of Economics and Statistics, 36(4), 409-414

Keynes M. (1936), The General Theory of Employment, Interest and Money, London, Macmillan

Koczan Z. (2015), 'Fiscal deficit and public debt in the Western Balkans: 15 years of transition', IMF Working Paper, WP/15/172, Washington DC, International Monetary Fund

Koczan Z. (2016), 'Being poor, feeling poorer: inequality, poverty and poverty perceptions in the Western Balkans', IMF Working Paper, WP/16/31, Washington DC, International Monetary Fund

Kovtun D. et al. (2014), 'Boosting job growth in the Western Balkans', IMF Working paper, WP/14/16, Washington DC, International Monetary Fund

Lapavitsas C. et al. (2010), 'Eurozone crisis: beggar thyself and thy neighbour', Journal of Balkan and Near Eastern Studies, 12(4), 321-373

Minsky H. (1986), Stabilizing an Unstable Economy, McGraw-Hill Professional

Országhová L. (2015), 'EU enlargement: euroisation in the Western Balkans (part III)', BIATEC (Journal of the Slovak National Bank), 2, 24-28

Palley T. (2007), 'Financialization: what it is and why it matters', Working Paper Series, 153, Political Economy Research institute, University of Massachusetts

Picketty T. (2014), Capital in the Twenty First Century, Harvard, Harvard University Press

Pisany-Ferry J. (2014), The Euro Crisis and its Aftermath, Oxford, Oxford University Press

Pula B. (2014), 'Effects of the European financial and economic crisis in Kosovo and the Balkans: modes of integration and transmission belts of crisis in the 'super-periphery", East European Politics, 30(4), 507-525

Sokol M. (2001), 'Central and Eastern Europe a decade after the fall of state-socialism: regional dimensions of transition processes', Regional Studies, 35(7), 645-655

Steindl J. (1952), Maturity and Stagnation in American Capitalism, Oxford, Basil Blackwell

Summers L. (2013), 'Why stagnation might prove to be the new normal', Financial Times, 15 December 2013

Werner-Sinn H. (2014), The Euro Trap: On Bursting Bubbles, Budgets and Beliefs, Oxford, Oxford University Press

World Bank (2014), 'Brittle Recovery', South East Europe Regular Economic Report, 6, Washington DC, The World Bank 